\title{
The Global Longitudinal Study of Osteoporosis in Women (GLOW): rationale and study design
}

\author{
F. H. Hooven - J. D. Adachi - S. Adami - S. Boonen - J. Compston • C. Cooper • \\ P. Delmas - A. Diez-Perez • S. Gehlbach • S. L. Greenspan • A. LaCroix • R. Lindsay • \\ J. C. Netelenbos • J. Pfeilschifter • C. Roux • K. G. Saag • P. Sambrook • S. Silverman • \\ E. Siris • N. B. Watts • F. A. Anderson Jr
}

Received: 5 December 2008 / Accepted: 21 April 2009 / Published online: 26 May 2009

(C) The Author(s) 2009. This article is published with open access at Springerlink.com

\begin{abstract}
Summary The Global Longitudinal study of Osteoporosis in Women (GLOW) is a prospective cohort study involving 723 physicians and 60,393 women subjects $\geq 55$ years. The data will provide insights into the management of fracture
\end{abstract}

Pierre Delmas is deceased.

F. H. Hooven $(\bowtie) \cdot$ F. A. Anderson Jr

Center for Outcomes Research, University of Massachusetts

Medical School, 365 Plantation Street, Suite 185,

Worcester, MA 01605, USA

e-mail: fred.hooven@umassmed.edu

\section{J. D. Adachi}

St. Joseph's Hospital, McMaster University,

Hamilton, Ontario, Canada

\section{S. Adami}

Department of Rheumatology, University of Verona,

Ospedale, Verona,

Valeggio, Italy

\section{S. Boonen}

Leuven University Center for Metabolic Bone Diseases,

Division of Geriatric Medicine, Katholieke Universiteit Leuven,

Leuven, Belgium

\section{J. Compston}

School of Clinical Medicine, Addenbrooke's Hospital,

University of Cambridge,

Cambridge, UK

C. Cooper

MRC Epidemiology Resource Centre,

University of Southampton, Southampton General Hospital,

Southampton, UK

\section{Cooper}

Institute of Musculoskeletal Sciences,

University of Oxford,

Oxford, UK risk in older women over 5 years, patient experience with prevention and treatment, and distribution of risk among older women on an international basis.

Introduction Data from cohort studies describing the distribution of osteoporosis-related fractures and risk

P. Delmas

Department of Rheumatology, Hôpital Edouard Herriot,

5 Place d'Arsonval,

Lyon, France 69437

A. Diez-Perez

Hospital del Mar-IMIM-Autonomous University of Barcelona,

Barcelona, Spain

S. Gehlbach

Center for Outcomes Research,

University of Massachusetts Medical School,

Worcester, MA, USA

\section{S. L. Greenspan}

University of Pittsburgh,

Pittsburgh, PA, USA

\section{A. LaCroix}

Fred Hutchinson Cancer Research Center,

Seattle, WA, USA

R. Lindsay

Regional Bone Center, Helen Hayes Hospital,

West Haverstraw, NY, USA

J. C. Netelenbos

Department of Endocrinology,

VU University Medical Center,

Amsterdam, The Netherlands

J. Pfeilschifter

Alfried Krupp Krankenhaus, Department of Internal Medicine III,

Essen, Germany 
factors are not directly comparable and do not compare regional differences in patterns of patient management and fracture outcomes.

Methods The GLOW is a prospective, multinational, observational cohort study. Practices typical of each region were identified through primary care networks organized for administrative, research, or educational purposes. Noninstitutionalized patients visiting each practice within the previous 2 years were eligible. Self-administered questionnaires were mailed, with 2:1 oversampling of women $\geq 65$ years. Follow-up questionnaires will be sent at 12-month intervals for 5 years.

Results A total of 723 physicians at 17 sites in ten countries agreed to participate. Baseline surveys were mailed (October 2006 to February 2008) to 140,416 subjects. After the exclusion of 3,265 women who were ineligible or had died, 60,393 agreed to participate.

Conclusions GLOW will provide contemporary information on patterns of management of fracture risk in older women over a 5-year period. The collection of data in a similar manner in ten countries will permit comparisons of patient experience with prevention and treatment and provide insights into the distribution of risk among older women on an international basis.

Keywords Fracture - Osteoporosis · Prevention .

Risk factors $\cdot$ Treatments $\cdot$ Women

\section{Roux}

Centre D'Evaluation Des Maladies Osseuses, Hôpital Cochin,

Paris, France

K. G. Saag

Division of Clinical Immunology and Rheumatology,

University of Alabama-Birmingham,

Birmingham, AL, USA

P. Sambrook

University of Sydney-Royal North Shore Hospital,

St. Leonards,

Sydney, New South Wales, Australia

S. Silverman

Department of Rheumatology, David Geffen School of Medicine,

Los Angeles, CA, USA

E. Siris

Columbia University Medical Center,

New York, NY, USA

N. B. Watts

Bone Health and Osteoporosis Center, University of Cincinnati, Cincinnati, OH, USA

\section{Introduction}

A number of cohort studies have detailed the distribution of osteoporosis-related fractures and their accompanying risk factors in different regions of the world [1-18]. As these studies varied in their objectives and methods of data collection, the comparability of the information obtained may be limited. Furthermore, existing reports do not compare regional differences in patterns of patient management and outcomes of fracture.

The Global Longitudinal study of Osteoporosis in Women (GLOW) is an observational longitudinal study designed to improve understanding of international patterns of susceptibility, recognition, management, and outcomes of care in women aged 55 years and older at risk for fragility fractures. The aim of the GLOW study is to collect uniform data to: (1) describe the distribution of risk factors for osteoporosisrelated fracture; (2) apply published fracture risk assessment tools in a population of older women; (3) identify differences in physician patterns of diagnosis and management of osteoporosis (e.g., how health care providers are identifying individuals for treatment; characteristics of women being treated); (4) characterize factors that influence patient persistence with treatment, including patient characteristics, awareness of fracture risk and comorbid conditions; (5) assess the real-world effectiveness of care on the incidence of fracture; and (6) evaluate the cost effectiveness of interventions for the prevention and management of osteoporosis from the perspective of the health care provider.

\section{Study design}

Study site selection

GLOW is being conducted in physician practices in 17 study sites in ten countries (Australia, Belgium, Canada, France, Germany, Italy, Netherlands, Spain, UK, and USA) in Australia, Europe, and North America. These sites are located in major population centers (Table 1). A Scientific Advisory Board comprising investigators at each of the 17 sites was constituted to provide scientific oversight and study management. These individuals are independent university-based investigators with content expertise in osteoporosis, who represent the disciplines of endocrinology, rheumatology, geriatric medicine, and epidemiology. These sites were selected based on the ability of the local investigators to consistently administer the survey methodology, on the availability of a wide spectrum of osteoporosis treatment options and bone densitometry, and the existence of prior studies in those regions, which would provide data for comparison with the GLOW sample. Practical considerations concerning the number of survey 
Table 1 Study sites and number of patients enrolled per site

\begin{tabular}{|c|c|c|c|c|}
\hline Region & \multicolumn{2}{|l|}{ Site } & Physicians & Patients \\
\hline Australia & \multicolumn{2}{|l|}{ Sydney } & 51 (GP) & 2,904 \\
\hline Canada & \multicolumn{2}{|l|}{$\begin{array}{l}\text { Hamilton, } \\
\text { Ontario }\end{array}$} & 35 (GP) & 3,985 \\
\hline \multirow[t]{8}{*}{ Europe } & Belgium & Leuven & 31 (GP) & 3,692 \\
\hline & \multirow[t]{2}{*}{ France } & Lyon & 52 (GP) & 3,366 \\
\hline & & Paris & 45 (GP) & 1,714 \\
\hline & Germany & Essen & 39 (GP) & 3,465 \\
\hline & Italy & Verona & 44 (GP) & 3,252 \\
\hline & Netherlands & Amsterdam & 14 (GP) & 2,856 \\
\hline & Spain & Barcelona & 62 (GP) & 2,910 \\
\hline & UK & Southampton & 52 (GP) & 4,079 \\
\hline \multirow[t]{7}{*}{ USA } & \multicolumn{2}{|l|}{$\begin{array}{l}\text { Birmingham, } \\
\text { Alabama }\end{array}$} & $\begin{array}{l}9 \text { (FP) } \\
33 \text { (IM) }\end{array}$ & 5,061 \\
\hline & \multicolumn{2}{|l|}{$\begin{array}{l}\text { Cincinnati, } \\
\text { Ohio }\end{array}$} & $\begin{array}{l}8 \text { (FP) } \\
14 \text { (IM) }\end{array}$ & 3,128 \\
\hline & \multicolumn{2}{|l|}{$\begin{array}{l}\text { Los Angeles, } \\
\text { California }\end{array}$} & $\begin{array}{l}20(\mathrm{FP}) \\
16(\mathrm{IM})\end{array}$ & 3,102 \\
\hline & \multicolumn{2}{|l|}{$\begin{array}{l}\text { Pittsburgh, } \\
\text { Pennsylvania }\end{array}$} & $\begin{array}{l}5(\mathrm{FP}) \\
15(\mathrm{IM})\end{array}$ & 4,233 \\
\hline & \multicolumn{2}{|c|}{$\begin{array}{l}\text { Rockland County, } \\
\text { New York }\end{array}$} & $\begin{array}{l}1(\mathrm{FP}) \\
71(\mathrm{IM})\end{array}$ & 3,500 \\
\hline & \multicolumn{2}{|l|}{$\begin{array}{l}\text { Seattle, } \\
\text { Washington }\end{array}$} & $\begin{array}{l}55(\mathrm{FP}) \\
7(\mathrm{IM})\end{array}$ & 4,055 \\
\hline & \multicolumn{2}{|c|}{$\begin{array}{l}\text { Worcester, } \\
\text { Massachusetts }\end{array}$} & $\begin{array}{l}5(\mathrm{FP}) \\
39(\mathrm{IM})\end{array}$ & 5,091 \\
\hline
\end{tabular}

$G P$ general practice, $F P$ family practice, $I M$ internal medicine

translations and number of countries in which the survey process could be supervised restricted the number of sites to those chosen for this study.

Physician sample selection

Practices typical of each region were recruited through primary care networks organized for administrative, research, or educational purposes or by identifying all physicians in a geographic area. Physician networks included regional health-system-owned or managed practices, health maintenance organizations, independent practice associations, and other primary care practice networks.
Networks established for the purpose of general medical research were used only if they were not established exclusively for osteoporosis research and did not consist of physicians whose primary focus was academic.

Primary care physicians were defined as physicians who spent the majority of their time providing primary health care to patients. Depending on the country in which the study site was located, this included internists, family practitioners, and general practitioners who provide primary care. If the physician network or study area included more eligible physicians than were required to recruit a sufficient number of patients, a random sample of those physicians within the network or study was invited.

Each physician completed a standardized form that collected data on their demographics and practice characteristics (Table 2).

\section{Patient selection}

Each physician practice provided a list of the names and addresses of women aged 55 years and older who had consulted their physician in the past 24 months. These lists comprised the sampling frame. Sampling was stratified by age to ensure that two thirds of the women surveyed were 65 years of age and older. In each practice, we recruited from all eligible women 65 and over and a random sample of half that number under age 65 years. Sample size estimates were generated to detect a $30 \%$ difference in 5year fracture incidence between treated and untreated patients with a power of $80 \%$. On this basis, a sample of approximately 3,000 patients was sought at each site. Patients were excluded if they were unable to complete the study survey due to cognitive impairment, language barriers, or institutionalization or were too ill.

Instrument development

Questionnaires were designed to be self-administered and cover the domains outlined in Table 3. Where possible, items from published validated instruments were used, including the National Health and Nutrition Examination Survey (NHANES) [19], EuroQol (EQ-5D) [20], and SF-36 [21] (physical function component). Questions that had not

Table 2 Physician data

Country, state/province and postal code

Demographics: sex and age

Primary and secondary specialties

Percentage of time devoted to primary and secondary specialties

Number of patients in the physician's panel

Practice type: solo, single specialty group, multispecialty group, size of group

Availability of on-site bone mineral density testing 
Table 3 Baseline questionnaire items

\begin{tabular}{|c|c|}
\hline Item & Questions \\
\hline $\begin{array}{l}\text { Patient characteristics } \\
\text { and risk factors }\end{array}$ & $\begin{array}{l}\text { Age; race (US only); current height; } \\
\text { height at age 25; current weight; heigh } \\
\text { loss in past year; education level; years } \\
\text { since last menstrual period; maternal } \\
\text { history of osteoporosis; parental hip } \\
\text { fracture; falls in past } 12 \text { months; arms } \\
\text { needed to assist in standing from a } \\
\text { chair; fractures since age } 45 \text {; smoking } \\
\text { status; alcohol use }\end{array}$ \\
\hline $\begin{array}{l}\text { Perception about fracture } \\
\text { risk and osteoporosis }\end{array}$ & $\begin{array}{l}\text { Level of concern about osteoporosis; } \\
\text { talked with doctor about osteoporosis } \\
\text { patient told she has osteoporosis or } \\
\text { osteopenia; talked with doctor about } \\
\text { fall prevention; ever had bone density } \\
\text { test; perception of fracture risk; } \\
\text { perception of osteoporosis risk }\end{array}$ \\
\hline $\begin{array}{l}\text { Medication use (currently } \\
\text { taking or ever taken) }\end{array}$ & $\begin{array}{l}\text { Prescription bone medications (country } \\
\text { specific); calcium; vitamin D; } \\
\text { estrogen or hormone replacement; } \\
\text { cortisone or prednisone; anastrozole; } \\
\text { exemestane; letrozole; tamoxifen }\end{array}$ \\
\hline $\begin{array}{l}\text { Comorbidities } \\
\text { (ever diagnosed) }\end{array}$ & $\begin{array}{l}\text { Asthma; chronic bronchitis or } \\
\text { emphysema; osteoarthritis; rheumatoid } \\
\text { arthritis; stroke; ulcerative colitis or } \\
\text { Crohn's disease; celiac disease; } \\
\text { Parkinson's disease; multiple sclerosis; } \\
\text { cancer; type 1 diabetes; hypertension; } \\
\text { heart disease; high cholesterol }\end{array}$ \\
\hline Health care use and access & $\begin{array}{l}\text { Patient has health coverage (country } \\
\text { specific); nights of hospitalization in } \\
\text { past year; visits to doctor in past year }\end{array}$ \\
\hline Physical activity & $\begin{array}{l}\text { Number of days when walked } \geq 20 \text { min in } \\
\text { past } 30 \text { days; level of activity compared } \\
\text { with other women of the same age. }\end{array}$ \\
\hline $\begin{array}{l}\text { Physical function and } \\
\text { quality of life }\end{array}$ & $\begin{array}{l}\text { SF-36 physical function component; } \\
\text { EQ-5D }\end{array}$ \\
\hline
\end{tabular}

been used previously were tested cognitively in the context of the complete questionnaire in a sample of women in the study age group. The complete baseline questionnaire was also pilot-tested before being finalized to gauge subject comprehension and completion time. Questionnaires were translated into five languages (French, Spanish, German, Italian, and Dutch) in addition to English by the University of Massachusetts-Amherst Translation Center. Where items from existing questionnaires had been translated previously, these items were incorporated directly. Translations were reviewed by study coordinators at each site for accuracy and consistency with local idiom. Because NHANES is administered to a representative sample of US residents, it was possible to compare responses to items that were similar in the GLOW survey to assess the similarity of the populations. Data from NHANES conducted in 2005 and 2006 were used for this purpose.
Survey administration

Each study site obtained ethics committee approval to conduct the study in the specific location. Baseline questionnaires along with invitations to participate in the study signed by the local principal investigator were mailed to all potential patients. Nonrespondents were followed up with a series of postcard reminders, second questionnaires, and telephone interviews, as outlined in Fig. 1. Women who responded will be resurveyed annually for the next 4 years. In addition to repeating questions about medications, quality of life, and functional status, the follow-up surveys will include questions about persistence with medication, reasons for nonadherence, and detail about fracture-associated treatment.

Patient identity is safeguarded by the local study coordinator, who assigns an ID number to each participant at enrollment and maintains the site's participant list locally. The names of patients are stored separately from study data transmitted to the central coordinating center (Center for Outcomes Research at the University of Massachusetts Medical School). Thus, unique patient identifiers are confidential to the investigators at each study site.

The process for entering, verifying, and managing survey data is uniform across all study sites. Completed questionnaires are sent to the central coordinating center, where they are scanned electronically, and data fields are audited visually by a person trained to process the forms. The data entry software is designed to detect out-of-range values, inconsistencies, and omissions and to document any resolutions. Scanned data are entered into a database stored on a secured password-protected computer. As a quality control measure, each study site maintains an administrative database that tracks surveys mailed and received, and scanned surveys are checked against these databases. Twice yearly meetings are held with study coordinators from each of the study sites to review survey administration and ensure uniformity of the process. For study sites using telephone follow-up in addition to mail, a standard telephone script is used and reviewed with each site to ensure consistency of telephone survey administration.

\section{Results}

A total of 723 physicians agreed to participate in the GLOW study and supplied practice lists. The number of physicians ranged from 14 to 72 per site (median 40). In the US, 298 participating physicians comprised 103 family physicians and 195 internal medicine physicians. All Canadian, Australian, and European participants were general practitioners.

Baseline surveys were mailed between October 2006 and February 2008 to 140,416 potential subjects (Fig. 1). After 


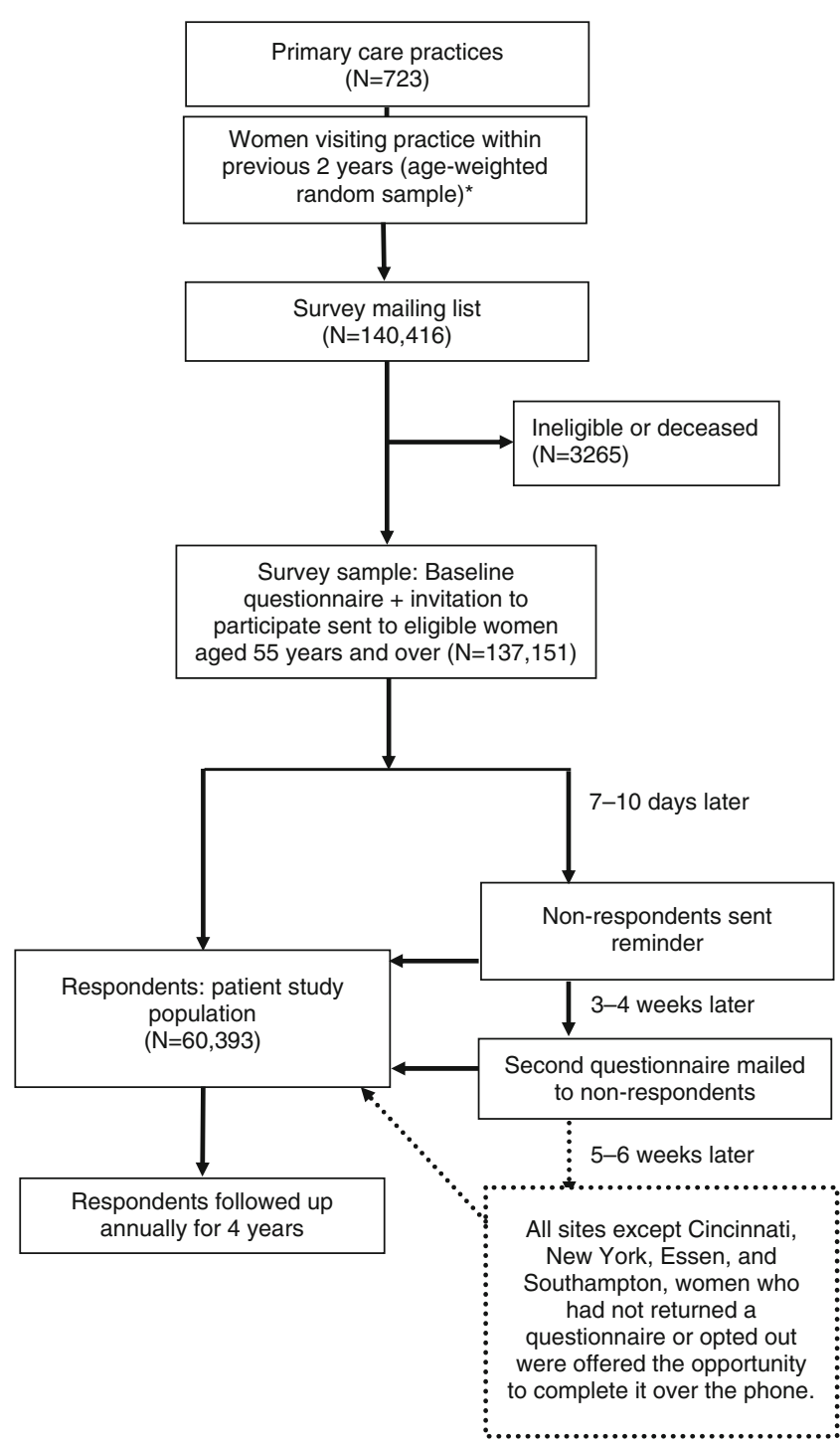

Fig. 1 Recruitment/enrollment flow chart. Asterisk, age-stratified sampling not feasible in Sydney, Paris, or Lyon

the exclusion of 3,265 patients who were either ineligible or had died, 60,393 women agreed to participate. The median response rate among the 17 study sites was $62 \%$ (range $15-75) ; 76 \%$ of the study sites had a response rate of $50 \%$ or greater. Two sites experienced notably lower response rates than were typical. In both Italy and Spain, the lower response to mailed surveys had been anticipated based on prior experience with mail surveys in those regions; accordingly, higher numbers of surveys were sent to potential participants in order to collect the targeted 3,000 responses.

The characteristics of the 60,393 women who participated in GLOW are displayed in Table 4. The mean age was 69 years and mean weight $148 \mathrm{lb}(67.2 \mathrm{~kg})$. Among characteristics known to place women at increased risk of fragility fracture, weight $<125 \mathrm{lb}(57 \mathrm{~kg})$ was present in
$16 \%$, history of maternal hip fracture in $13 \%$, and personal history of a fracture of the wrist, spine, or hip in $12 \%$. Twenty-two percent had been told by a doctor or health professional that they had osteoporosis; $11 \%$ reported asthma, and $11 \%$ rheumatoid arthritis; $23 \%$ of women said their health status was "fair" or "poor."

Comparisons of demographic characteristics and risk factors for the US GLOW subjects and for women aged 55 and older sampled in the NHANES study (2005 to 2006) are also displayed in Table 4. Although the mean ages for the two groups were similar, women in the GLOW sample had received a higher level of education, were more often white, and had better self-reported health than women in the NHANES study. History of wrist fracture was also somewhat lower in the GLOW population than in the NHANES population. However, many of the risk factors were similar among the two samples, for example low weight, osteoporosis diagnosis, fracture of the spine or hip, and maternal fracture. The prevalence of common comorbid conditions, such as hypertension, high cholesterol, and asthma, was also similar.

When women were asked how concerned they were about osteoporosis, 54\% expressed "some" concern and $25 \%$ said they were "very concerned" about the condition (Table 5). Overall, 43\% said they had spoken with their doctor about osteoporosis testing, treatment, or prevention in the past 12 months. Twenty-one percent of women reported having been told by their doctor or health provider that they had osteoporosis; $19 \%$ said they were told they had osteopenia. When asked to rate their own risk of getting osteoporosis compared with women their own age, $33 \%$ rated their risk as lower and $19 \%$ as higher.

\section{Discussion}

GLOW is designed to provide an international perspective on fracture risk in women, patient management practices, patient awareness, physical and emotional function following fracture, application of risk assessment models, and functional outcomes following fracture. Previous cohort studies of osteoporosis were designed primarily to identify factors associated with fracture incidence and document the distribution of low bone mineral density and its association with fracture risk. These efforts have been limited to specific regions or areas. GLOW will provide the first description of patterns of risk from an international perspective. Further, the data from GLOW will be used to assess not only fracture risk and incidence, but will identify patient concern and awareness and clinical management at a time when significant efforts have been made to implement treatment guidelines and educate patients about osteoporosis and fracture risk. In these baseline results, a 
Table 4 Characteristics of women participating in GLOW, US women participating in GLOW, and NHANES women aged 55 years and older for 2005 to 2006

\begin{tabular}{|c|c|c|c|}
\hline & $\begin{array}{l}\text { All GLOW women } \\
(n=60,393)\end{array}$ & $\begin{array}{l}\text { US GLOW women }{ }^{\mathrm{a}} \\
(n=28,170)\end{array}$ & NHANES women (2005-2006) \\
\hline Mean age, years (SE) & $69(0.04)$ & $69(0.05)$ & $68(0.32)$ \\
\hline Mean weight, lb (SE) & $148(0.3)$ & $159(0.2)$ & $163(1.0)$ \\
\hline \multicolumn{4}{|l|}{$\%$} \\
\hline Weight< 125 lb (57 kg) & 16 & 15 & 16 \\
\hline Broken wrist $^{\mathrm{b}}$ & 8.7 & 7.4 & $9.8^{\mathrm{c}}$ \\
\hline Broken spine $^{b}$ & 2.3 & 1.9 & $1.6^{\mathrm{c}}$ \\
\hline Broken hip ${ }^{b}$ & 1.9 & 2.1 & $2.1^{\mathrm{c}}$ \\
\hline Maternal hip fracture & 13 & 13 & $11^{\mathrm{c}}$ \\
\hline \multicolumn{4}{|l|}{ Ever diagnosed with } \\
\hline Asthma & 11 & 14 & 12 \\
\hline Chronic bronchitis or emphysema & 9 & 9.1 & 12 \\
\hline High cholesterol & 50 & 57 & 54 \\
\hline Hypertension & 51 & 56 & 56 \\
\hline Osteoporosis & 22 & 20 & $24^{\mathrm{c}}$ \\
\hline Osteoarthritis or degenerative joint disease & 40 & 32 & 24 \\
\hline Rheumatoid arthritis & 11 & 9.4 & 8.5 \\
\hline General health "fair or poor" & 23 & 15 & 22 \\
\hline Non-Hispanic white & NA & 86 & 80 \\
\hline \multicolumn{4}{|l|}{ Education level } \\
\hline Less than high school & NA & 7.4 & 23 \\
\hline High school & NA & 26 & 30 \\
\hline More than high school & NA & 67 & 47 \\
\hline
\end{tabular}

$N A$ not available, $S E$ standard error

${ }^{\text {a }}$ Frequencies are age-standardized to the whole GLOW population

b Fractures are since age 45 in GLOW, "ever" in NHANES

${ }^{\mathrm{c}}$ Data are from NHANES 2003 to $2004(n=1,108)$, the latest year with these data available

minority of GLOW subjects (43\%), among women 55 years and older, indicated having discussed osteoporosis with their physician in the past year, yet $79 \%$ of women in the study were somewhat or very concerned about osteoporosis. Future analyses of GLOW data will examine the link between perceived risk, concern, and physician encounters on treatment risk of fracture and quality of life.

Prior studies have reported undertreatment and underdiagnosis of osteoporosis [22]. However, since these studies were conducted, many new therapies have become more widely used than in the past. GLOW will report on contemporary treatment prevalence according to fracture risk and self-reported diagnosis of osteoporosis at a time when a wider range of patient management options have been generally accepted and are available

Previously collected risk factor data form the basis for risk-scoring algorithms designed to predict fracture risk and aid physicians in targeting treatment to those most in need [23-26]. GLOW will update data on these factors and allow the calculation of patterns of international fracture risk.
Because the data will be gathered in a consistent manner, confidence will be increased that the variations seen in the distribution of risk factors between regions is due to differences in the populations rather than in the methods of data collection.

Table 5 Subjects' awareness of osteoporosis

Percent

Concern about osteoporosis

Very concerned 25

Somewhat concerned 54

Talked with their doctor about osteoporosis $\quad 43$

Doctor told subject she had osteoporosis 21

Doctor told subject she had osteopenia $\quad 19$

Self-rated risk of osteoporosis

Lower 33

Higher $\quad 19$ 
The study will also assess a spectrum of physicianpatient interactions including discussion of osteoporosis, advice concerning falls, bone mineral density screening, diagnosis of osteoporosis, and pharmacological treatments. Regional and international comparisons of diagnosis and treatment patterns will be possible, with adjustment for region- and country-specific characteristics, such as the availability of health insurance, reimbursement for prescriptions, and treatment protocols. A number of items that assess subjects' physical and emotional status have also been incorporated in the questionnaire. These include the mobility and vitality scales from SF-36 and the five subscales of the EQ-5D. Such measures will enable comparisons of functional outcomes for women who suffer various types of incident fractures in differing geographic regions over time.

Whereas most studies of patient persistence focus on a single drug, GLOW will include the full range of currently available pharmacological treatments for osteoporosis (alendronate, calcitonin, estrogen, etidronate, ibandronate, pamidronate, parathyroid hormone [1-84], raloxifene, risedronate, strontium ranelate, teriparatide, tibolone, and zoledronate). We will also be able to include any newly available osteoporosis medications in the questionnaire. The study will also examine the reasons why patients stop and switch medications.

GLOW data will allow assessment of the effectiveness of treatment on the incidence of fracture in a "real-world" setting. In contrast to randomized clinical trials, GLOW did not exclude women who had previously been diagnosed with osteoporosis or treated with bone drugs. Consequently, analysis of the treated population will include those women who stop or switch medications, as well as those who have a high degree of persistence. Adjustment will be possible for potential confounding of the relationship between treatment and fracture using fracture risk factors and risk scores. While the study is not designed to evaluate the effectiveness of any single bone drug, it will allow comparison of fracture rates among treated and untreated patients across all classes of interventions. Such head-tohead comparisons have not been evaluated in randomized controlled trials.

Analysis will also be carried out to estimate the relative cost effectiveness of various classes of interventions used in the management of fractures, using the usual principles set out for cost-effectiveness analysis [27-29]. An economic model based on the epidemiological evidence of treatment outcomes recorded in GLOW will be constructed [30].

GLOW is a practice-based rather than a populationbased study and is subject therefore to biases in both the selection of physicians and the sampling and recruitment of patients. Practical considerations limited our sample selection to women from 17 study locations in ten countries. An expanded sample that included a broader representation of racial and ethnic groups was not pursued because of the complexity of administering a recruitment methodology involving oversampling of particular racial and ethnic groups in ten different countries, where the definitions of these groups were likely to vary considerably. Physicians at each site who agreed to participate may not be representative of all physicians in an area with respect to osteoporosis recognition and management. We attempted to avoid altering physician practice by minimizing doctors' awareness of the study. There were no clinical interventions and physicians had no involvement in patient recruitment other than supplying practice lists.

Unlike studies that excluded women because of prior fracture, diagnosis of osteoporosis, or current treatment for osteoporosis, GLOW attempted to enlist all women 55 years and older who were active patients in each physician's practice. By doing so, the study will provide a more complete picture of care received by women in this age group. Nonetheless, some participation biases are likely. It is possible that participants will have greater interest in bone health issues and seek information, screening, and treatment more actively. We attempted to reduce selection bias by creating a survey process that imposed low respondent burden. Participation required no clinic visits (by not requiring patients to schedule a clinic visit or faceto-face interview, we avoid requirements that might make participation difficult for women who are in poor health or have no or limited access to transportation) and questionnaires were mailed directly to the subject's home and typically required only $15-20 \mathrm{~min}$ to complete. High response rates at most sites (median 62\%) suggest that this strategy was successful. Comparison of characteristics for the sample of US women with those of the nationally representative sample of comparably aged NHANES women demonstrated that although GLOW women were better educated, more likely to be white, and reported better health, the prevalence of risk factors for fracture was similar.

All data are collected by patient self-report. While this approach is subject to limitations of recall and recall bias, it has the advantages of efficiency and methodological consistency. The combination of mail and telephone surveys is amenable to collection of data on quality of life, health status, and fracture risk factors of interest. The efficiency of the mail and phone survey approach also makes it feasible to obtain a substantial sample size and to provide adequate statistical power for the analysis of fracture outcomes, which are relatively rare events. The survey format also allows standardized administration that reduces the issues of noncomparability and variation in data quality that would arise if medical records and public health care databases from several different countries were used. Reports that have examined the validity of self-report of 
prescription medication use and fractures have shown reasonable accuracy [31-36]. Self-report may be preferable to the abstraction from medical records of data on diagnosis and treatment, given inconsistencies in record keeping between physicians and between study regions and countries. Additionally, records from primary care physicians may not include evidence of treatment initiated by a specialist physician. Validation of self-reports of variables such as fractures and bone mineral density examinations may be possible for subsets of subjects in sites where electronic medical records are available.

\section{Conclusions}

GLOW will provide important information on the patterns of management of fracture risk in older women over a 5year period. The collection of data in a similar fashion in ten countries will allow comparisons of patient experience with prevention and treatment, and an understanding of differences in the distribution of risk among older women on an international basis.

\begin{abstract}
Acknowledgment We thank the physicians and project coordinators participating in GLOW, Allison Wyman, MS, for performing the statistical analyses, and Sophie Rushton-Smith, Ph.D., for editorial support. The GLOW study is supported by a grant from The Alliance for Better Bone Health (Procter \& Gamble Pharmaceuticals and sanofiaventis) to The Center for Outcomes Research, University of Massachusetts Medical School. Dr. Boonen is senior clinical investigator of the Fund for Scientific Research, Flanders, Belgium (F.W.O.-Vlaanderen) and holder of the Leuven University Chair in Metabolic Bone Diseases.
\end{abstract}

Funding GLOW is sponsored by a grant from The Alliance for Better Bone Health (Procter \& Gamble Pharmaceuticals and sanofi-aventis).

Conflicts of interest Frederick H Hooven: The Alliance for Better Bone Health (Procter \& Gamble Pharmaceuticals and sanofi-aventis).

Jonathan D Adachi: Research grant Consultant/Speaker: Amgen, Astra Zeneca, Eli Lilly, GlaxoSmithKline, Merck, Novartis, Nycomed, Pfizer, Procter \& Gamble, Roche, sanofi-aventis, Servier, Wyeth and Bristol-Myers Squibb. Clinical trials for Amgen, Eli Lilly, GlaxoSmithKline, Merck, Novartis, Pfizer, Procter \& Gamble, Roche, sanofi-aventis, Wyeth and Bristol-Myers Squibb. Stock: nothing to declare.

Silvano Adami: Speakers' bureau: Merck Sharp and Dohme, Lilly, Roche, Procter \& Gamble, Novartis; Honoraria: Merck Sharp and Dohme, Roche, Procter \& Gamble; Consultant/Advisory Board: Merck Sharp and Dohme, Amgen.

Steven Boonen: Research grant: Amgen, Eli Lilly, Novartis, Pfizer, Procter \& Gamble, sanofi-aventis, Roche, GlaxoSmithKline; Speakers' bureau: Amgen, Eli Lilly, Merck, Novartis, Procter \& Gamble, sanofi-aventis, Servier; Honoraria: Amgen, Eli Lilly, Merck, Novartis, Procter \& Gamble, sanofi-aventis, Servier; Consultant/Advisory Board: Amgen, Eli Lilly, Merck, Novartis, Procter \& Gamble, sanofi-aventis, Servier.

Juliet Compston: Paid consultancy work: Servier, Shire, Nycomed, Novartis, Amgen, Procter \& Gamble, Wyeth, Pfizer, Alliance for Better
Bone Health, Roche, GlaxoSmithKline. Paid speaking engagements, reimbursement, and travel and accommodation: Servier, Procter \& Gamble, Eli Lilly. Research grants from Servier R\&D and Procter \& Gamble. No stocks or shares in relevant companies.

Cyrus Cooper: Received consulting fees and lectured for Amgen, Alliance for Better Bone Health, Eli Lily, Merck Sharp and Dohme, Servier, Novartis, and Roche-GSK.

Adolfo Diez-Perez: Honoraria: Novartis, Eli Lilly, Amgen, Procter \& Gamble, Roche; Expert Witness: Merck; Consultant/Advisory board: Novartis, Eli Lilly, Amgen, Procter \& Gamble.

Stephen Gehlbach: The Alliance for Better Bone Health (Procter \& Gamble Pharmaceuticals and sanofi-aventis).

Susan L Greenspan: Research grant: Lilly, Procter \& Gamble, Novartis, Amgen, Zelos; Other research support: Novartis, Wyeth; Honoraria: Procter \& Gamble for CME speaking; Consultant/Advisory Board: Amgen, Procter \& Gamble, Merck.

Andrea LaCroix: The Alliance for Better Bone Health (Procter \& Gamble Pharmaceuticals and sanofi-aventis).

Robert Lindsay: The Alliance for Better Bone Health (Procter \& Gamble Pharmaceuticals and sanofi-aventis).

J Coen Netelenbos: Research grant: sanofi-aventis, Procter \& Gamble; Speakers' bureau: Procter \& Gamble; Honoraria: GP Laboratories; Consultant/advisory board: Procter \& Gamble, Roche, GlaxoSmithKline, Nycomed.

Johannes Pfeilschifter: Research grant: AMGEN, Kyphon, Novartis, Roche; Other research support: Equipment: GE LUNAR; Speakers' bureau: AMGEN, sanofi-aventis, GlaxoSmithKline, Roche, Lilly Deutschland, Orion Pharma, Merck Sharp and Dohme, Merckle, Nycomed, Procter \& Gamble; Advisory Board membership: Novartis, Roche, Procter \& Gamble, TEVA.

Christian Roux: Honoraria: Alliance, Amgen, Lilly, Merck Sharp and Dohme, Novartis, Nycomed, Roche, GlaxoSmithKline, Servier, Wyeth; Consultant/Advisory board: Alliance, Amgen, Lilly, Merck Sharp and Dohme, Novartis, Nycomed, Roche, GlaxoSmithKline, Servier, Wyeth.

Kenneth G Saag: Speakers' bureau: Novartis; Consulting Fees or other remuneration: Eli Lilly \& Co., Merck, Novartis, Amgen, Roche, Proctor \& Gamble, sanofi-aventis; Paid research: Eli Lilly \& Co, Merck, Novartis, Amgen, Prector \& Gamble, sanofi-aventis; Advisory Committee or other paid committee: Eli Lily \& Co.

Philip Sambrook: Honoraria: Merck, sanofi-aventis, Roche, Servier; Consultant/Advisory board: Merck, sanofi-aventis, Roche, Servier.

Stuart Silverman: Research grants: Wyeth, Lilly, Novartis, Alliance; Speakers' bureau: Lilly, Novartis, Pfizer, Procter \& Gamble; Honoraria: Procter \& Gamble; Consultant/Advisory Board: Lilly, Amgen, Wyeth, Merck, Roche, Novartis.

Ethel S Siris: Speakers' bureau: Lilly, Merck, Procter \& Gamble, sanofi-aventis, Novartis.

Nelson B Watts: Stock options/holdings, royalties, company owner, patent owner, official role: none. Amgen: speaking, consulting, research support (through the university). Eli Lilly: consulting, research support (through the university). Novartis: speaking, consulting, research support (through the university). Novo Nordisk: consulting. Procter \& Gamble: speaking, consulting, research support (through the university). sanofi-aventis: speaking, consulting..

Frederick A Anderson: Research grant: sanofi-aventis: GRACE, GLOW, ENDORSE; The Medicines Company: STAT; Scios: Orthopedic Registry; Consultant/Advisory Board: sanofi-aventis, Scios, GlaxoSmithKline, The Medicines Company, Millennium Pharmaceuticals.

Pierre Delmas: None

Open Access This article is distributed under the terms of the Creative Commons Attribution Noncommercial License which permits any noncommercial use, distribution, and reproduction in any medium, provided the original author(s) and source are credited. 


\section{References}

1. Hays J, Hunt JR, Hubbell FA, Anderson GL, Limacher M, Allen C, Rossouw JE (2003) The Women's Health Initiative recruitment methods and results. Ann Epidemiol 13:S18-S77

2. Cummings SR, Nevitt MC, Browner WS, Stone K, Fox KM, Ensrud KE, Cauley J, Black D, Vogt TM (1995) Risk factors for hip fracture in white women. Study of osteoporotic fractures research group. N Engl J Med 332:767-773

3. Tanko LB, Bagger YZ, Nielsen SB, Christiansen C (2003) Does serum cholesterol contribute to vertebral bone loss in postmenopausal women? Bone 32:8-14

4. European Prospective Osteoporosis Study Group (2002) Incidence of vertebral fracture in Europe: results from the European Prospective Osteoporosis Study (EPOS). J Bone Miner Res 17:716-724

5. Hofman A, Grobbee DE, de Jong PT, van den Ouweland FA (1991) Determinants of disease and disability in the elderly: the Rotterdam Elderly Study. Eur J Epidemiol 7:403-422

6. O'Neill TW, Felsenberg D, Varlow J, Cooper C, Kanis JA, Silman AJ (1996) The prevalence of vertebral deformity in European men and women: the European Vertebral Osteoporosis Study. J Bone Miner Res 11:1010-1018

7. Ismail AA, Pye SR, Cockerill WC, Lunt M, Silman AJ, Reeve J, Banzer D, Benevolenskaya LI, Bhalla A, Bruges Armas J, Cannata JB, Cooper C, Delmas PD, Dequeker J, Dilsen G, Falch JA, Felsch B, Felsenberg D, Finn JD, Gennari C, Hoszowski K, Jajic I, Janott J, Johnell O, Kanis JA, Kragl G, Lopez Vaz A, Lorenc R, Lyritis G, Marchand F, Masaryk P, Matthis C, Miazgowski T, Naves-Diaz M, Pols HA, Poor G, Rapado A, Raspe HH, Reid DM, Reisinger W, Scheidt-Nave C, Stepan J, Todd C, Weber K, Woolf AD, O’Neill TW (2002) Incidence of limb fracture across Europe: results from the European Prospective Osteoporosis Study (EPOS). Osteoporos Int 13:565-571

8. Adachi JD, Loannidis G, Berger C, Joseph L, Papaioannou A, Pickard L, Papadimitropoulos EA, Hopman W, Poliquin S, Prior JC, Hanley DA, Olszynski WP, Anastassiades T, Brown JP, Murray T, Jackson SA, Tenenhouse A (2001) The influence of osteoporotic fractures on health-related quality of life in community-dwelling men and women across Canada. Osteoporos Int 12:903-908

9. Melton LJ 3rd, Crowson CS, O'Fallon WM, Wahner HW, Riggs BL (2003) Relative contributions of bone density, bone turnover, and clinical risk factors to long-term fracture prediction. J Bone Miner Res 18:312-318

10. Johansson H, Oden A, Johnell O, Jonsson B, de Laet C, Oglesby A, McCloskey EV, Kayan K, Jalava T, Kanis JA (2004) Optimization of BMD measurements to identify high risk groups for treatment $-\mathrm{a}$ test analysis. J Bone Miner Res 19:906-913

11. Jones G, Nguyen T, Sambrook PN, Kelly PJ, Gilbert C, Eisman JA (1994) Symptomatic fracture incidence in elderly men and women: the Dubbo Osteoporosis Epidemiology Study (DOES). Osteoporos Int 4:277-282

12. Johansson C, Black D, Johnell O, Oden A, Mellstrom D (1998) Bone mineral density is a predictor of survival. Calcif Tissue Int 63:190-196

13. Fujiwara S, Kasagi F, Yamada M, Kodama K (1997) Risk factors for hip fracture in a Japanese cohort. J Bone Miner Res 12:998-1004

14. Schott AM, Cormier C, Hans D, Favier F, Hausherr E, DargentMolina P, Delmas PD, Ribot C, Sebert JL, Breart G, Meunier PJ (1998) How hip and whole-body bone mineral density predict hip fracture in elderly women: the EPIDOS Prospective Study. Osteoporos Int 8:247-254

15. Gluer CC, Eastell R, Reid DM, Felsenberg D, Roux C, Barkmann R, Timm W, Blenk T, Armbrecht G, Stewart A, Clowes J,
Thomasius FE, Kolta S (2004) Association of five quantitative ultrasound devices and bone densitometry with osteoporotic vertebral fractures in a population-based sample: the OPUS Study. J Bone Miner Res 19:782-793

16. Sanders KM, Pasco JA, Ugoni AM, Nicholson GC, Seeman E, Martin TJ, Skoric B, Panahi S, Kotowicz MA (1998) The exclusion of high trauma fractures may underestimate the prevalence of bone fragility fractures in the community: the Geelong Osteoporosis Study. J Bone Miner Res 13:1337-1342

17. Anderson GL, Manson J, Wallace R, Lund B, Hall D, Davis S, Shumaker S, Wang CY, Stein E, Prentice RL (2003) Implementation of the Women's Health Initiative study design. Ann Epidemiol 13:S5-S17

18. Siris E, Miller P, Barrett-Connor E, Abbott T, Sherwood L, Berger M (1998) Design of NORA, the National Osteoporosis Risk Assessment Program: a longitudinal US registry of postmenopausal women. Osteoporos Int 8(Suppl 1):S62-S69

19. Haentjens P, Johnell O, Kanis JA, Bouillon R, Cooper C, Lamraski G, Vanderschueren D, Kaufman JM, Boonen S (2004) Evidence from data searches and life-table analyses for genderrelated differences in absolute risk of hip fracture after Colles' or spine fracture: Colles' fracture as an early and sensitive marker of skeletal fragility in white men. J Bone Miner Res 19:19331944

20. EuroQol Group (1990) EuroQol—a new facility for the measurement of health-related quality of life. Health Policy 16:199-208

21. Ware JE, Kosinski M, Dewey JE (2000) How to score version 2 of the SF-36 Health Survey. Quality Metric, Lincoln

22. Elliot-Gibson V, Bogoch ER, Jamal SA, Beaton DE (2004) Practice patterns in the diagnosis and treatment of osteoporosis after a fragility fracture: a systematic review. Osteoporos Int 15:767-778

23. Black DM, Steinbuch M, Palermo L, Dargent-Molina P, Lindsay R, Hoseyni MS, Johnell O (2001) An assessment tool for predicting fracture risk in postmenopausal women. Osteoporos Int 12:519-528

24. Cadarette SM, Jaglal SB, Kreiger N, McIsaac WJ, Darlington GA, Tu JV (2000) Development and validation of the Osteoporosis Risk Assessment Instrument to facilitate selection of women for bone densitometry. CMAJ 162:1289-1294

25. Robbins J, Aragaki AK, Kooperberg C, Watts N, WactawskiWende J, Jackson RD, LeBoff MS, Lewis CE, Chen Z, Stefanick ML, Cauley J (2007) Factors associated with 5-year risk of hip fracture in postmenopausal women. JAMA 298:2389-2398

26. Kanis JA, Johnell O, Oden A, Johansson H, McCloskey E (2008) FRAX and the assessment of fracture probability in men and women from the UK. Osteoporos Int 19:385-397

27. Drummond M, O'Brien B, Stoddart G, Torrance G (1997) Methods for the economic evaluation of health care programmes. Oxford University Press, Oxford

28. Gold M, Siegel J, Russell L, Weinstein M (1996) Costeffectiveness in health and medicine. Oxford University Press, New York

29. National Institute for Health and Clinical Excellence (2004) Guide to the methods of technology appraisal review process and timelines. http://www.nice.org.uk/niceMedia/pdf/GuideToTA MethodsReview.pdf

30. Borgstrom F, Jonsson B, Strom O, Kanis JA (2006) An economic evaluation of strontium ranelate in the treatment of osteoporosis in a Swedish setting: based on the results of the SOTI and TROPOS trials. Osteoporos Int 17:1781-1793

31. Hundrup YA, Hoidrup S, Obel EB, Rasmussen NK (2004) The validity of self-reported fractures among Danish female nurses: comparison with fractures registered in the Danish National Hospital Register. Scand J Public Health 32:136-143 
32. Curtis JR, Westfall AO, Allison J, Freeman A, Kovac SH, Saag KG (2006) Agreement and validity of pharmacy data versus selfreport for use of osteoporosis medications among chronic glucocorticoid users. Pharmacoepidemiol Drug Saf 15:710-718

33. Nevitt MC, Cummings SR, Browner WS, Seeley DG, Cauley JA, Vogt TM, Black DM (1992) The accuracy of self-report of fractures in elderly women: evidence from a prospective study. Am J Epidemiol 135:490-499

34. Chen Z, Kooperberg C, Pettinger MB, Bassford T, Cauley JA, LaCroix AZ, Lewis CE, Kipersztok S, Borne C, Jackson RD (2004) Validity of self-report for fractures among a multiethnic cohort of postmenopausal women: results from the Women's Health Initiative observational study and clinical trials. Menopause 11:264-274

35. Ismail AA, O'Neill TW, Cockerill W, Finn JD, Cannata JB, Hoszowski K, Johnell O, Matthis C, Raspe H, Raspe A, Reeve J, Silman AJ (2000) Validity of self-report of fractures: results from a prospective study in men and women across Europe. EPOS study group. European Prospective Osteoporosis Study group. Osteoporos Int 11:248-254

36. Honkanen K, Honkanen R, Heikkinen L, Kroger H, Saarikoski S (1999) Validity of self-reports of fractures in perimenopausal women. Am J Epidemiol 150:511-516 